\title{
The case of chronic clonazepam use in Rio de Janeiro through the voices of users
}

\section{El caso de uso crónico de clonazepam en Río de Janeiro en la voz de los usuarios}

\section{O caso do uso crônico de clonazepam no Rio de Janeiro pela voz dos usuários}

\author{
Rafaela Zorzanelli \\ ORCID ID: 0000-0001-7531-8492 \\ Universidade do Estado do Rio de Janeiro, UERJ, Brasil \\ Renata de Marca \\ ORCID ID: 0000-0001-9156-5530 \\ Universidade do Estado do Rio de Janeiro, UERJ, Brasil
}

Autor referente: rtzorzanelli@gmail.com

Historia Editorial

Recibido: 17/05/2018

Aceptado: 11/10/2018

\begin{abstract}
In Brazil, Rivotril (clonazepam) has gained a reputation as a social object. Its logo is emblazoned on everyday objects and the drug itself is the topic of online communities and featured on television programs. Method. We conducted in-depth, semi-structured interviews with a sample of adults (aged 18 and over) who lived in the state of Rio de Janeiro and who had been using Rivotril for over 12 months. Using the snowball technique, we collected an unintentional sample of 20 subjects over 18 years of age who lived
\end{abstract}

in Rio de Janeiro and who had been using the drug continuously for at least 12 months. Researchers presented the project to their social contacts, sending them emails in which they invited them to indicate people who fitted the inclusion criteria. Results. The key points of the analysis were: 1) the users developed "lay expertise" on the dosage of the drug; 2) whenever treatment was supervised by a psychiatrist, an antidepressant was prescribed together with the benzodiazepine; 3 ) once they started 
using clonazepam, the users' perception of their capacity to live without it changed; 4) although all the interviewees were long-term users, they did not see themselves as dependent on the drug. Discussion. The users customized, negotiated, and legitimized their use of clonazepam, from how much and how often they took it to their habits of sharing it. Further research investigating users' accounts of prescription drugs are needed to include their perceptions, which are frequently overlooked in the field of analysis.

Keywords: Psychotropic drugs; Mental health; Benzodiazepines; Clonazepam

\section{RESUMEN}

En Brasil, el Rivotril viene recibiendo destaque como objeto social. El logotipo de su marca aparece en diversos objetos de uso cotidiano, además de ser asunto en comunidades virtuales y programas de televisión. Métodos. Utilizamos la técnica de muestreo de bola de nieve y realizamos entrevistas de tipo semiestructuradas en profundidad en una muestra conformada por 20 individuos mayores de 18 años, residentes en el estado de Río de Janeiro, que habían hecho uso de Rivotril por por un periodo mayor a 12 meses. Los investigadores presentaron el proyecto en sus redes sociales, y enviaron e-mails solicitando la indicación de potenciales usuarios interesados en participar de la investigación. Resultados. Entre los puntos analiticos destacamos: 1) los usuarios desarrollaron un conocimiento lego sobre dosis; 2) cuando el tratamiento fue prescripto por psiquiatra, siempre incluyó también la prescripción de un antidepresivo junto al benzodiazepínico, 3) una vez iniciado el uso del clonazepam, la percepción de la capacidad de los pacientes de vivir sin ese medicamento se vió alterada; 4) a pesar de tratarse de usuarios cronicos, no se autoperciben como dependientes de la sustancia. Discusión. Los usuarios personalizaban, negociaban y legitimaban el uso de la sustancia, desde la cantidad, frecuencia y prácticas de compartirla. Nuevas investigaciones que incorporen relatos de usuarios de sustancias prescriptas deben ser realizadas, con el objetivo de incluir las percepciones de los propios usuarios, frecuentemente desconsideradas del campo de análisis.

\section{Palabras clave: Psicotrópicos; Salud mental; Benzodiazepínicos; Clonazepam}

\section{RESUMO}

No Brasil, o Rivotril tem recebido destaque como objeto social. O logotipo da marca aparece estampado em objetos de uso cotidiano, além de o medicamento ser assunto de comunidades virtuais e programas televisivos. Método. Utilizamos a técnica da bola de neve para chegar aos usuários e realizamos entrevistas em profundidade, com roteiro semiestruturado com uma amostra de 20 pessoas maiores de 18 anos, residentes no Estado do Rio de Janeiro, que utilizaram o medicamento por mais de 12 meses. Os pesquisadores apresentaram o projeto e enviaram e-mails para suas redes de contato social, solicitando que indicassem potenciais usuários interessados em participar da pesquisa. Resultados. Dentre os pontos analíticos, destacam-se: 1) os usuários desenvolveram uma "expertise leiga" sobre as dosagens; 2) sempre que o 
tratamento era supervisionado por um psiquiatra, um antidepressivo era prescrito junto com o benzodiazepínico; 3) uma vez iniciado o uso do clonazepam, a percepção de sua capacidade de viver sem 0 medicamento se alterava; 4) embora se tratassem de usuários de longo-prazo, eles não se percebiam como dependentes da substância. Discussão. Os usuários customizavam, negociavam e legitimavam o uso da substância, desde a quantidade, a frequência $e$ as práticas de compartilhamento. Mais pesquisas que investiguem o relato de usuários de substâncias prescritas deve ser realizados, no intuito de incluir as percepções dos usuários, que são frequentemente desconsiderados do campo de análise.

Palavras-chave: Psicotrópicos; Saúde mental; Benzodiazepínicos; Clonazepam

$\mathrm{T}$ he attribution of meaning to the use of prescribed substances based on the accounts of their users is the main subject of interest in this article. The abuse of illicit substances has long featured in humanities and health science research. However, less care and attention has been paid to the problematic uses of prescribed substances-ones that are legal and can only be acquired with a doctor's prescription-especially in low- and middle-income countries.

Unlike other classes of medicines, psychotropic substances-especially depressants, like benzodiazepines and opioids, and stimulants, like amphetamine and its derivatives-have introduced into the debate certain concepts like tolerance, dependence, addiction, specificities about their consumption, negotiated use, sharing between users, acquisition or obtainment strategies, dosage regulation, and frequency of use. There are not all that many differences between these issues and the ones discussed when it comes to illicit substances, which begs some questions about the theoretically imposed distinction between licit/illicit drugs and medical/non-medical uses. Furthermore, as Cohen, McCubbin, Collin, \& Pérodeau (2001) point out, performance- and mood-enhancing drugs have become cultural icons well known throughout society, especially Prozac, Ritalin, and Viagra. Unlike other classes of medicines, like antibiotics or high blood pressure medicines, the level of social distinction associated to the obtainment, use of, and knowledge about these 
substances seems to be a determining factor in the life cycle they develop as biotechnologies (Geels, Pieters \& Snelders, 2007). In Brazil, the consumption of psychotropic drugs and the ways they are used have become the target of increasing research interest, especially the rational use of psychiatric drugs in different cities around the country (Noto et al., 2002; Galduróz, Noto, Nappo \& Carlini, 2005).

There are some key interfaces between groups, communities, and individuals that need to be considered when it comes to prescribed substances. In the case of psychotropic drugs, certain theoretical concepts, such as medicalization (Conrad, 2007), biomedicalization (Clarke, Shim, Mamo, Fosket \& Fishman, 2003), pharmaceuticalization (Abraham, 2010; Williams, Martin \& Gabe, 2008), overdiagnosis, and overprescribing (Wieteke van Dijk, Faber, Tanke, Jeurissen \& Westert, 2016), are important for considering the status of different medicines in urban western societies, especially in view of the significant differences between high-income and low- and middle-income countries. Another key factor is the rising number of psychiatric diagnoses and the rise in the off-label use of psychotropic drugs, together with the power the drug industry exerts over the institutions engaged in the production of knowledge (Angell, 2004).

Latin America has some distinctive dilemmas, insofar as the abuse of prescription drugs coexists paradoxically with poor access to and coverage of health services and/or basic medications (Zorzanelli, Ortega \& Bezerra, 2014). In Brazil, for instance, studies that have investigated the increasing vulnerability of socially underprivileged groups and how this impacts their health and their access to health services have compared users of the public health service, which is supposed to be universal, comprehensive, and equitable, with users of private health services that have health insurance to map out differences between populations, contexts, regions, states, communities, and social, economic and cultural aspects. While such mapping may fall outside the scope of this work, what we plan to do here is to show how processes such 
as medicalization, pharmaceuticalization, biomedicalization, overdiagnosis, and overprescribing-depending on what approach the researcher takes—only make sense if considered on a case-by-case basis, taking local realities into account.

The case in question - the consumption of clonazepam by a sample of users from the state of Rio de Janeiro-seems to us a suitable way of reflecting on the social dynamics in which we live, as well as the values, contradictions, and ultimately the perceptions about health and disease at stake. There are few studies that have used qualitative approaches to address the problematic use of prescribed substances in Brazil, specifically based on the accounts of chronic benzodiazepine users. Although it is important for users to be aware of the pros and cons of the long-term use of benzodiazepines, this study steers clear of any moralizing or stigmatizing bias towards such users or their usage habits. It is important, from a qualitative perspective, to go beyond the scope of the concept of rational use (Cohen et al., 2001) and give voice to the consumers themselves, drawing closer to the concept of the "irrational" use of medicines, observing the role these substances play in the life of each subject, the trajectories of use of the drug, the strategies the users employ to manage its use and dosage, their expectations concerning its use, and the meanings constructed in the their relationship with the benzodiazepine.

\section{The presence of Rivotril in Brazil}

Clonazepam, the active ingredient of Rivotril, produced by Roche, is classified as a benzodiazepine-a class of drugs with a hypnotic, sedative, anxiolytic, anticonvulsant effect (Charney, Mihic \& Harris, 2005). Benzodiazepines first hit the world market in the 1960s, but it was only in the following decade that their use really took off as they started to replace barbiturates, being perceived as safer, with fewer side effects, and offering a higher margin between the therapeutically effective dose and toxicity (Charney et al., 2005). However, some researchers have found that their continuous 
use could generate tolerance and abstinence syndrome (Charney et al., 2005), and others have found their prolonged use to be associated with cognitive impairment (Gage et al., 2014) and falls in older users (Rezende, Gaede-Carrillo \& Sebastião, 2012).

In Brazil, data on benzodiazepine sales, prescriptions, and consumption patterns are limited. However, key improvements of the Brazilian health regulatory agency, ANVISA, mostly introduced in the last decade, have afforded the development of an important dataset on the prescription patterns of benzodiazepines in Brazil. Since 2009, the National System for the Management of Controlled Substances (Sistema Nacional de Gerenciamento de Produtos controlados, SNGPC) has been gathering data on prescribed substances from registered pharmacies all over the country. In 2012, ANVISA, produced an online pharmacoepidemiological map showing the top selling controlled substances in each state of the country (ANVISA, 2012). According to the map, between 2009 and 2011, clonazepam was the most consumed active ingredient of all the manufactured formulations listed in Ministry of Health directive SVS/MS 344/1998 (which regulates substances subject to special control) in at least $77 \%$ of the states in the country. Although this map provides retail data on a very short period of time, what is interesting is that the pattern of sales of clonazepam was extremely homogeneous across different regions of the country. Brazil has widely varying levels of quality of life, human development indices, and demographics in its different regions, states, and municipalities. Nonetheless, clonazepam was the most widely used benzodiazepine every year from 2009 to 2011 in such different states as Acre, Rondônia, Rio de Janeiro, and Rio Grande do Sul, which is certainly noteworthy, even if this data only covers the first three years of the SNGPC system. Something else that draws attention is the way Rivotril has been incorporated into Brazilian mass culture: it appears on magazine covers, on cell phone covers, on household objects, and in online communities. These products emblazoning Rivotril's images are easily 
found in commercial websites and internet search tools. It has been the subject of light entertainment shows on TV, included in the lyrics of pop songs, and has appeared in countless memes that have gone viral across different social media. More than an agglomerate of molecules that affects the central nervous system, clonazepam has infiltrated popular culture, becoming something of a fetish, an object of desire and social distinction - which could actually seem paradoxical given how inexpensive it is in Brazil.

\section{Benzodiazepines: link between the sacred and the profane}

The theoretical references we will draw upon come from the anthropology of medicines. As argued by van der Geest and Whyte (1989), medicines are things, and as things, they have a sort of concreteness, a quality of being tangible, and they are believed to contain the power of healing in themselves. As such, pharmaceutical efficacy is regarded as a multivalent concept that involves different dimensions, ranging from individual biology to sociocultural dynamics. Recognizing that drugs are concrete material objects with concrete biomolecular effects does not prevent them from also being analyzed as complex social phenomena embedded in the web of individual and collective meanings and interactions.

The concreteness of medicines grants them a metonymic function that enables medical expertise (the knowledge embodied symbolically in the physician) to be incorporated into the pills, the drops, or whatever form it is that the medical substance takes. This concreteness allows their users to appropriate their uses and effects beyond the descriptions made of them in the discourses of those authorized to speak in their name, such as biomedical discourse. "Medicines are widely believed to contain the power of healing in themselves. Anyone who gains access to them can apply their power" (van der Geest \& Whyte, 1989, p.345). Meanwhile, Lefévre (1983) sustains that medicines enact a magical reduction of what should be complex and abstract into 
something simple and concrete, emptying out the multiple meanings that permeate all the symbolic space between the drug and the consumer and turning it into just one more object of consumption. It is, then, easy for there to be an overlapping of meanings in medicines in general and in psychotropic drugs in particular if we consider their action on the central nervous system and their capacity to affect moods, behaviors, and perceptions of self and the world.

In this superimposition of meanings, medicines become forms of merchandise imbued with healing powers that can be acquired like any consumer good, forming an intersection between the commercial and the magical, the sacred and the profane. These interwoven meanings often fail to take into account the potentially harmful effects of the inappropriate use of medicines, especially benzodiazepines, as if they were the source of benefits alone. As Cohen et al. (2001) put it, "the veritable impact of iatrogenic effects of drugs is barely known. This ignorance constitutes an inconspicuous but extremely powerful bias toward the 'natural' view of medications as primarily essential, lifesaving products and the intent of prescription as necessarily therapeutic" (p.458).

Without doubt, the transformation from a magic object (capable of healing, preventing, or altering states of consciousness) into accessible merchandise does not come about without some form of coherent ritual within the cosmology of biomedicine, involving the need, to some extent, to conform to the wisdom and rites of western medicine (consultations, diagnoses, prescriptions, etc.), even if these rites may occur in the absence of their enacters - such as the prescribers themselves.

Another key point for our analysis has to do with the particularities of the life cycle of psychotropic drugs - the trajectory they take from their conception as a molecule to their use in association with a given symptom or disease until their eventual disuse or rebirth for other purposes (Pieters \& Snelders, 2007; Geels et al., 2007). As Cohen et al. (2001) explain, "few medications remain in significant use as remedies for the class 
of problems for which they were initially indicated and marketed, after a few decades" (p.446). The main point for the subject at hand is the fact that the factors that influence the trajectory of a drug do not just have to do with doctors and patients; they also have to do with the removal of a drug from the market, its approval for sale over the counter, the appearance of new therapeutic indications, the public and private exchange of information about the drug and its use, what is published or broadcast in the mass media, and what information is passed on and shared amongst users through different channels, with social media playing a particular part in this process.

\section{Research design}

We collected an unintentional sample using the snowball technique. During the sampling process, there were no specific criteria, such as gender or educational level, although these variables will be important elements in further analysis. The inclusion criteria were: subjects over 18 years of age, who may be receiving psychiatric treatment or not, and who have been using the drug continuously for at least 12 months and are still using it at the time of the interview, not necessarily on a regular basis. Researchers presented the project to their social contacts, sending them emails in which they invited them to indicate people who fitted the inclusion criteria. After receiving each indication of a long-term user interested in collaborating, the members of the research group contacted these users by email or phone to arrange a time to conduct the interview. By the end of 2017, 20 clonazepam users who fitted the research criteria had been interviewed: 13 in 2015-2016 and seven in 2017. Four declined to participate after being contacted by phone, email, or text message. None of the subjects is related to any of the researchers. The users were enrolled on the study and given an in-depth, semi-structured interview by qualified interviewers. This paper presents the analysis of the first 20 interviews of the intended total of 50 . The study, the consent forms, and all the other documents were approved by the research ethics 
committee (registered under CAAE 30889214.2.0000.5260). Below there is a brief description of the research subjects and a few of their socio-demographic details.

Table 1

Participants- sociodemographic data

\begin{tabular}{|c|c|c|c|c|c|c|}
\hline & Sex & Age & $\begin{array}{l}\text { Civil } \\
\text { Status }\end{array}$ & $\begin{array}{l}\text { Household } \\
\text { income }\end{array}$ & Education Level & $\begin{array}{l}\text { Length of } \\
\text { use (years) }\end{array}$ \\
\hline S1 & $F$ & 52 & Divorced & $\square 2 \times \mathrm{MW}^{*}$ & $\begin{array}{c}\text { High school } \\
\text { graduate }\end{array}$ & 4 \\
\hline S2 & $F$ & 62 & Single & 4-10x MW & $\begin{array}{c}\text { Postgraduate } \\
\text { level }\end{array}$ & 12 \\
\hline S3 & $\mathrm{F}$ & 55 & Married & $\begin{array}{c}10-20 x \\
M W\end{array}$ & $\begin{array}{l}\text { High school } \\
\text { graduate }\end{array}$ & 12 \\
\hline S4 & $F$ & 60 & Married & $\square 20 \times \mathrm{MW}$ & $\begin{array}{l}\text { University } \\
\text { graduate }\end{array}$ & 6 \\
\hline S5 & $F$ & 89 & Widowed & $\begin{array}{c}\text { Not } \\
\text { informed }\end{array}$ & $\begin{array}{l}\text { University } \\
\text { graduate }\end{array}$ & 2 \\
\hline S6 & M & 42 & Married & 4-10x MW & $\begin{array}{c}\text { Postgraduate } \\
\text { level }\end{array}$ & 3 \\
\hline S7 & $F$ & 61 & Single & $\square 2 x \mathrm{MW}$ & $\begin{array}{l}\text { Middle education } \\
\text { incomplete }\end{array}$ & 15 \\
\hline S8 & $\mathrm{F}$ & 63 & Married & $\begin{array}{c}\text { Not } \\
\text { informed }\end{array}$ & $\begin{array}{l}\text { High school } \\
\text { graduate }\end{array}$ & 20 \\
\hline S9 & $\mathrm{F}$ & 34 & Divorced & $4-10 x \mathrm{MW}$ & $\begin{array}{c}\text { Postgraduate } \\
\text { level }\end{array}$ & 9 \\
\hline S10 & $F$ & 58 & Divorced & $\begin{array}{l}10-20 x \\
M W\end{array}$ & $\begin{array}{l}\text { Postgraduate } \\
\text { level }\end{array}$ & 26 \\
\hline S11 & $F$ & 74 & Single & $2 x \mathrm{MW}$ & $\begin{array}{l}\text { High school } \\
\text { graduate }\end{array}$ & 20 \\
\hline S12 & $F$ & 80 & Widowed & 4-10x MW & $\begin{array}{l}\text { High school } \\
\text { graduate }\end{array}$ & 13 \\
\hline S13 & $F$ & 61 & Married & $>2 \times M W$ & $\begin{array}{l}\text { High school } \\
\text { graduate }\end{array}$ & $\begin{array}{c}10 \\
\text { (estimated) }\end{array}$ \\
\hline S14 & M & 51 & $\begin{array}{c}\text { Civil } \\
\text { Partnershi } \\
p\end{array}$ & 4-10x MW & $\begin{array}{l}\text { University } \\
\text { graduate }\end{array}$ & $\begin{array}{c}7 \\
\text { (estimated) }\end{array}$ \\
\hline S15 & M & 34 & Single & 4-10x MW & $\begin{array}{c}\text { Postgraduate } \\
\text { level }\end{array}$ & 1,5 \\
\hline S16 & $\mathrm{F}$ & 27 & Single & $2-4 \times M W$ & $\begin{array}{l}\text { University } \\
\text { graduate }\end{array}$ & 8 \\
\hline S17 & M & 58 & Married & 4-10x MW & $\begin{array}{l}\text { Postgraduate } \\
\text { level }\end{array}$ & 8 \\
\hline S18 & $M$ & 21 & Single & 4-10x MW & $\begin{array}{l}\text { Undergraduate } \\
\text { degree } \\
\text { incomplete }\end{array}$ & $\begin{array}{c}5 \\
\text { (estimated) }\end{array}$ \\
\hline S19 & $F$ & 59 & Married & $\begin{array}{c}\text { Not } \\
\text { informed }\end{array}$ & $\begin{array}{l}\text { High school } \\
\text { graduate }\end{array}$ & 14 \\
\hline
\end{tabular}




\begin{tabular}{llllcl} 
& & Sing school & 10-20x \\
MW & $F$ & Single & graduate & 20 \\
& & & & (estimated) \\
\hline
\end{tabular}

Note. ${ }^{*} \mathrm{MW}=$ minimum wage

Table 1 demonstrates how pervasive in terms of education, age-group, and household income Rivotril is, being used by everyone from people who failed to complete their primary education to those with advanced academic degrees, different age groups, and different incomes. Most of the subjects are women, which is consistent with other epidemiologic studies (Olfson, King \& Schoenbaum, 2015). Concerning the length of use, six subjects had been using the drug continuously for two to six years (30\%), ten had been using it for seven to 15 years $(50 \%)$, and four had been using it for more than 20 years (20\%). Only five of them were under 50 years of age; nine were married, three were divorced, five were single, and two were widowed. Their income range was wide, spanning from two to 20 times the minimum wage.

In the data analysis, the interview transcripts were read through with the aim of gradually organizing the information supplied by the participants. The texts were read in depth until the saturation point was reached, using content analysis. The subject matter was organized into subsets, forming units of meaning. After the main topics in the accounts had been identified and analyzed, these units of meaning were constructed, summing up and organizing the users' reflections and the nuances revealed in each of their experiences.

\section{Presentation of research findings}

Although we do not have a representative sample, it is worth highlighting some of the most significant analytical points observed in the interviews so far. While the content appears here in separate topics illustrated by the participants' own words, the topics were often intertwined with one another or even reappeared at different points in the same interviews. 
1. The users develop a lay expertise on the drug's dosages, including "customized" methods for using and sharing it. These uses of the drug run parallel to the prescribed regimens. The users adjust their dosage themselves, without consulting their doctor, increasing it when they feel anxious or tense and decreasing it when they feel sedated. Some share their supply of the medication with close relatives (spouses, children) and friends, and recommend specific dosages to other people close to them. They take their treatment into their own hands: once they have a prescription from one doctor, they can carry on for years getting other prescriptions for the same drug from other specialists, without any follow-up on the complaint that led to their being prescribed the drug in the first place. The users tailor its dosage, varying it accordingly to their perceived needs:

"These days I take a $0.5 \mathrm{mg}$ pill at night, and when I need it I take $0.25 \mathrm{mg}$ during the day, when I feel chest pain." (S8)

“Sometimes he [her son] asks me for some pills, because he's run out. So then I share with him. He's already had it for treatment, but that was years ago." (S3)

“... as my problems got worse, I upped the dose myself. Until in 2014 when I got up to four milligrams." (S18)

"The problem is.... with Rivotril, the sky's the limit, right?... 0.25 is, like, it relaxes you.... Then after some time, nothing less than $2 \mathrm{mg}$ will calm you down." (S17)

There is a clear dividing line in the users' accounts between before and after their first use of clonazepam. As they adapted to its regular use, they effected a change in their relationship with their emotional limits - emotions that might trigger a crisis or the symptoms that caused them to use the substance in the first place. After the first outbreak of the crisis and settling into regular use, they become more attuned to their own mood swings and attempt to address them, preventing potential crises, through the use of the drug. 
When they were asked specifically about the side effects or possible harmful effects of the chronic use of Rivotril, most of the users tended to shrug off any side effects and blame themselves for memory lapses or falls, for example. In other words, after a while they stop perceiving any benefits of the drug, but at the same time they attribute hardly any actual harm to the long-term use of the drug (however likely this might be from a medical perspective):

"I don't know.... The fact is, I'm forgetful. I don't know if I'm more or less because of Rivotril." (S9)

"I've been taking it for a long time and.... I thought that really it was just.... harmless, because it wasn't really working.... But anyway, I still took it. Then I had a fall at home and broke my leg. (S5)

2. In the cases analyzed here, whenever treatment was supervised by a psychiatrist, an antidepressant was usually prescribed along with the benzodiazepine, but when the subjects compared the effects of clonazepam with the side-effects of the antidepressants (anesthesia, loss of libido), they preferred using clonazepam continuously to dealing with the antidepressants' side effects.

"Yes. $6 \mathrm{mg}$ [of clonazepam]. I mean, after a while it.... But I refused.... to.... take the.... antidepressant." (S10);

"All the drugs [antidepressants] have done me more harm than good.... And Rivotril even today, it isn't.... it doesn't, it doesn't cause me any problems." (S12)

3. We found that once clonazepam becomes part of a patient's daily life, their own perception of their capacity to live without it is blurred and they no longer feel able to live without the drug because they feel insecure about how they would cope without it and/or they feel like they are always on the brink of a breakdown.

"Oh, I'm.... I'm.... I'm afraid of stopping and having that [shortness of breath] again." 
"Well.... my psychiatrist, there was this time that she suggested [stopping taking] Rivotril, and I said, take away all the antidepressants but keep the Rivotril..." (S10) Also, the way the users describe their relationship with clonazepam often indicates its use not so much to relieve uncontrolled emotions as to grant protection, as if the drug were a protective object, since just having it with them, nearby, within their sight or close to hand, seems to make them feel safe from the threat of a panic attack or other untoward symptoms:

“... I think that if I didn't know it's there in my drawer.... that would make me quite nervous .... Like, I carry it around in my purse if anything is making me feel bad... " (S16)

“... I hardly use Rivotril anymore. I keep it in my purse and all..." (S15).

4. Although they were long-term users (with between 18 months and 26 years of continuous use, although not necessarily on a regular basis during the interview period), they did not feel they were drug-dependent.

“... the effect, it's not, you know, like it was at the start. I don't know if it's because I've been taking it for so long, but I don't use it all the time. I haven't become dependent on it." (S13)

“Well, I'm the kind of person that doesn't have any compulsions. I'm not the addictive sort, you know? So perhaps that helps me not to get dependent on Rivotril." (S10)

Generally speaking, findings have pointed out that there is an intriguing value judgment about the drug, which most of the users perceive as innocuous (in terms of its actual expected effects as well as its adverse effects and risks), while at the same they have no intention of stopping using its continuous use. In their own words:

"I don't feel different any more when I take it." ( S7)

"It doesn't really do anything anyway". (S10)

"As a user, I take it like a 'chemical cup of tea.' Like grandma's chamomile tea. It's a little white pill. [laughs] That simple." (S14) 
Yet despite these claims, they wouldn't consider stopping using it. Why would one not want to stop using a drug that "made no difference at all"? Even though we have only dealt with a small number of subjects until now, these preliminary results indicate some issues worth investigating in the future.

\section{Discussion}

According to the accounts collected in our research, clonazepam seems to operate in different dimensions - sometimes as an protective object that prevents new crises from breaking out (even without immediately being used), sometimes as an object of consumption, sometimes as a badge of social distinction. This distinction derives from multiple sources: possession of information about the existence of a substance capable of regulating and perhaps even stopping acute suffering; or the fact of owning it and being able to share it and one's own experiences with others. The risk-avoidance rhetoric found in the sample - avoiding the recurrence of unwanted symptoms - is very paradoxical: in order not to have a relapse of the kind of episode that originally triggered the use of clonazepam, the users keep taking it continuously or regularly, despite reporting that they no longer feel any of its beneficial effects. Avoiding the risk of a crisis and the immediate action of the substance were the key justifications given for chronic consumption of clonazepam by this sample of users.

As Collin (2016) has noted, the chronic use of prescription substances has specific effects on identity and social interaction. On one level, being able to share the medicine and the experience of using it with others offers a place of distinction and prestige, making experienced users potentially more skilled (and thus entitled to advise others) in how to use the drug and, ultimately, how to self-regulate their emotions. This is a bargaining chip used in the users' social exchanges, based on providing support when others have experiences similar to their own and sharing their own experiences of emotional suffering and of the effects of the drug. From learning about its use and its 
effects, experiencing taking other psychotropic drugs, drawing comparisons between them, and detecting threatening emotions in oneself that one would rather stifle by chemical means, it is but a short road to offering the drug to others (friends and family) and sharing it without the oversight of a prescriber. What stands out, therefore, is a kind of management of the emotions that is also taught to the uninitiated (who have not yet used the drug), between the limits of what kind of suffering is tolerable and what should not be borne. Indeed, this begs the question as to whether access to and management of drugs like clonazepam does not itself somehow end up altering sociocultural perceptions of the limit at which chemical intervention is called for when an individual is experiencing suffering, or, to put it differently, if the frontiers of what we call tolerable suffering are not also altered by the existence of and access to this kind of medicine.

Geels et al. (2007) have shown that in the trajectory of psychotropic drugs, ever since they first emerged there has always been a push-and-pull between enthusiasm and resistance. In this sense, the prescription and use of medicines produce not just passive acceptance, but tensions and non-compliance. Our understanding is that the contradictory positions expressed in the discourse of the subjects in this sample demonstrate "the ambivalent use of medical knowledge" (Ortega et al., 2013). It is clear that the users do call on the authority of a medical practitioner to get rid of symptoms of suffering and ensure a ready supply of drug prescriptions, when applicable, but they also express an interest in commenting on the benefits obtained to people close to them. However, once armed with this information, the use, dosage, and management of the drug is no longer decided upon simply in consultations with a doctor. The patients/users draw on their own knowledge of their own suffering to make judgments about how much they can or cannot tolerate, customizing, negotiating, and legitimizing their use of the drug accordingly. If our purpose is to formulate more effective policies that reflect a change in the mindset concerning the problematic use of 
benzodiazepines, we should include this "rationale of irrationality," which goes against the logic of the proper biomedical use of medicines, and which is so often summarily dismissed from the field of analysis as "misuse".

One of the limitations of the analysis made so far is that it does not explore correlations between the findings and the sociodemographic data obtained, such as sex, age group, and level of education. As far as education is concerned, for instance, the fact that the sample stemmed from contacts made by the researchers could have resulted in the recruitment of users whose education level is above the average in Brazil, as indicated by the recruitment of just one user with middle education incomplete. More indepth study is required, primarily to correlate the qualitative findings with the sociodemographic indicators like social class, age, ethnicity, and gender.

\section{References}

Abraham, J. (2010). Pharmaceuticalization of Society in Context: Theoretical, Empirical and Health Dimensions. Sociology, 44(4), 603-622. doi:10.1177/0038038510369368

Angell, M. (2004). A verdade sobre os laboratórios farmacêuticos (6th. ed). Rio de Janeiro, Brasil: Record.

ANVISA (BR). (2012). Mapa Interativo de Farmacoepidemiologia. Retrieved from http://portal.anvisa.gov.br/sngpc

Charney, D. S., Mihic, S. J., \& Harris, R. A. (2005). Hipnóticos e Sedativos. En Goodman Gilman, A. (Ed.), As bases farmacológicas da terapêutica (pp.303324). Rio de Janeiro, Brasil: Mc Graw Hill.

Clarke, A. E., Shim, J. K., Mamo, L., Fosket, J. R., \& Fishman, J. R. (2003). Biomedicalization: Technoscientific Transformations of Health, Illness, and U.S. Biomedicine. American Sociological Review, 68(2), 161-194. doi:10.2307/1519765 
Cohen, D., McCubbin, M., Collin, J., \& Pérodeau, G. (2001). Medications as social phenomena. Health, London, 5(4), 441-469. doi:10.1177/136345930100500403

Collin, J. (2016). On social plasticity: the transformative power of pharmaceuticals on health, nature and identity. Sociology of Health \& Illness, 38(1), 73-89. doi:10.1111/1467-9566.12342

Conrad, P. (2007). The medicalization of society. Baltimore, Maryland: The John Hopkins University Press.

Gage, S. B., Moride, Y., Ducruet, T., Kurth, T., Verdoux, H., Tournier, M., ... Bégaud, B. (2014). Benzodiazepine use and risk of Alzheimer's disease: case-control study. British Medical Journal, 349, 1-10. doi:10.1136/bmj.g5205

Galduróz, J. C. F., Noto, A. R., Nappo, S. A., \& Carlini, E. A. (2005). Uso de drogas psicotrópicas no Brasil: pesquisa domiciliar envolvendo as 107 maiores cidades do país-2001. Revista Latino-Americana de Enfermagem, 13(número especial), 888-895. Retrieved from http://www.scielo.br/scielo.php?pid=S010411692005000700017\&script=sci_abstract\&tIng=pt. doi: 10.1590/S010411692005000700017

Geels, F.W., Pieters, T., \& Snelders, S. (2007). Cultural enthusiasm, resistance and the societal embedding of new technologies: psychotropic drugs in the 20th century. Technology Analysis \& Strategic Mangement, 19(2), 145-165. doi: $10.1080 / 09537320601168052$

Lefévre, F. (1983). A função simbólica dos medicamentos. Revista de Saúde Pública, São Paulo, 17(6), 500-503. Retrieved from http://www.scielo.br/scielo.php?pid=S003489101983000600007\&script=sci_abstract\&tIng=pt. doi: 10.1590/S003489101983000600007

Noto, A. R.; Carlini, E. A., Mastroianni, P. C., Alves, V. C., Galduróz, J. C. F., Kuroiwa, ... Nappo, S. A. (2002). Analysis of prescription and dispensation of 
psychotropic medications in two cities in the State of São Paulo, Brazil. Revista

Brasileira de Psiquiatria, 24(2), 68-73. Retrieved from http://www.scielo.br/scielo.php?script=sci_arttext\&pid=S151644462002000200006 doi: 10.1590/51516-44462002000200006

Olfson, M., King, M.; \& Schoenbaum, M. (2015). Benzodiazepine use in the United $\begin{array}{llll}\text { States. } & \text { JAMA } & \text { Psychiatry, }\end{array}$ 10.1001/jamapsychiatry.2014.1763

Ortega, F., Zorzanelli, R. T., Meierhoffer, L. K., Rosário, C. A., Almeida, C. F., Andrada, B. F. C. C., ... Feldman, C. (2013). A construção do diagnóstico do autismo em uma rede social virtual brasileira. Interface (Botucatu), 17(44), 119-132. Retrieved from http://www.scielo.br/scielo.php?script=sci_arttext\&pid=S141432832013000100010 doi: $10.1590 / S 1414-32832013000100010$

Pieters, T., \& Snelders, S. (2007). From King-Kong pills to mother`s little helpers career cycles of two families of psychotropic drugs: the barbiturates and benzodiazepines. Canadian Bulletin of Medical History, 24(1), 93-112. doi: 10.3138/cbmh.24.1.93

Rezende, C. P., Gaede-Carrillo, M. R. G., \& Sebastião, E. C. O. (2012). Queda entre idosos no Brasil e sua relação com o uso de medicamentos: revisão sistemática. Cadernos de Saúde Pública, Rio de Janeiro, 28(12), 2223-2235. Retrieved from http://www.scielo.br/scielo.php?script=sci_arttext\&pid=S0102311X2012001400002 doi:10.1590/S0102-311X2012001400002

van der Geest, S., \& Whyte, S.R. (1989). The charms of medicines: metaphors and metonyms. Medical Anthropology Quarterly, 3(4), 345-367. doi: 10.1525/maq.1989.3.4.02a00030

Wieteke van Dijk, M. J., Faber, M. A.C., Tanke, P. P.T., Jeurissen, G. P., \& Westert, G. P. (2016). Medicalisation and Overdiagnosis: What Society Does to Medicine. 
International Journal of Health Policy and Management, 5(11), 619-622. doi:10.15171/IJHPM.2016.21

Williams, S., Martin, P., \& Gabe, J. (2008). The sociology of pharmaceuticals: progress and prospects. Sociology of health and illness, 30(6), 813-824. doi:10.1111/j.1467-9566.2008.01123.x.

Zorzanelli, R. T., Ortega, F., \& Bezerra Jr., B. (2014). Um panorama sobre as variações em torno do conceito de medicalização entre 1950-2010. Ciência e Saúde Coletiva, 19(6), 1859-1868. Retrieved from http://www.scielo.br/scielo.php?pid=S1413-

$81232014000601859 \&$ script=sci_abstract\&tlng=es.

doi:10.1590/141381232014196.03612013

\section{Formato de citación}

Zorzanelli, R., \& De Marca, R. (2018). The case of chronic clonazepam use in Rio de Janeiro through the voices of users. Psicología, Conocimiento y Sociedad, 8(2), 194213. doi: http://dx.doi.org/10.26864/PCS.v8.n2.10 